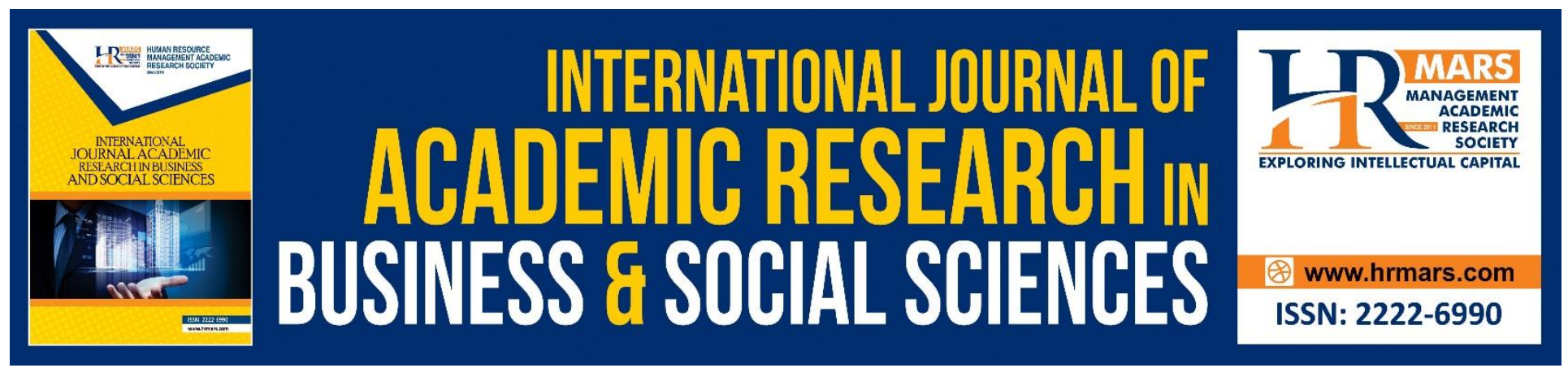

\title{
Error Analysis in Translation of Quotations in Online News Feature
}

Anis Shahirah Abdul Sukur \& Rokiah Awang

To Link this Article: http://dx.doi.org/10.6007/IJARBSS/v10-i7/7455

DOI:10.6007/IJARBSS/v10-i7/7455

Received: 10 April 2020, Revised: 14 May 2020, Accepted: 22 June 2020

Published Online: 30 July 2020

In-Text Citation: (Sukur \& Awang, 2020)

To Cite this Article: Sukur, A. S. A., \& Awang, R. (2020). Error Analysis in Translation of Quotations in Online News Feature. International Journal of Academic Research in Business and Social Sciences, 10(7), 526-540.

Copyright: (C) 2020 The Author(s)

Published by Human Resource Management Academic Research Society (www.hrmars.com)

This article is published under the Creative Commons Attribution (CC BY 4.0) license. Anyone may reproduce, distribute, translate and create derivative works of this article (for both commercial and non-commercial purposes), subject to full attribution to the original publication and authors. The full terms of this license may be seen at: http://creativecommons.org/licences/by/4.0/legalcode

Vol. 10, No. 7, 2020, Pg. 526 - 540

Full Terms \& Conditions of access and use can be found at http://hrmars.com/index.php/pages/detail/publication-ethics 


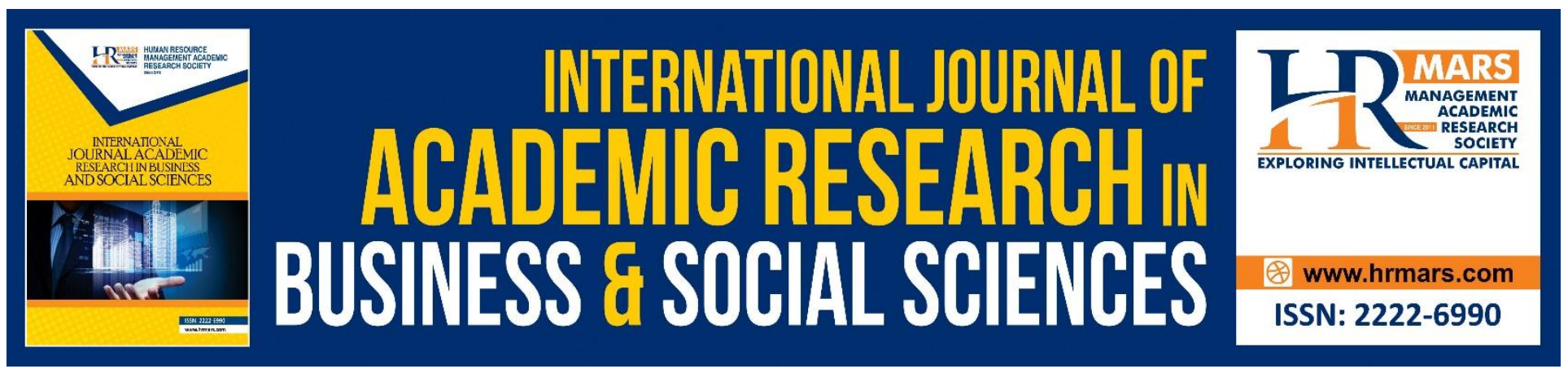

\title{
Error Analysis in Translation of Quotations in Online News Feature
}

\author{
Anis Shahirah Abdul Sukur \& Rokiah Awang \\ School of Humanities, Universiti Sains Malaysia \\ Email: sha_anis@usm.my \& arokiah@usm.my
}

\begin{abstract}
Error is an important aspect to consider, among other news elements, in order to overcome mistranslation. This is due to the fact that news translation encounters language and cultural barriers that may hinder total understanding of a news message (Conway, 2010). Error analysis is a method to document language errors that occur in a specific language. Therefore, this error analysis research is conducted to identify and pinpoint common translation errors that occur in online news feature. This research data is comprised of 859 quotations extracted from news feature published online by BERNAMA, the Malaysian national news agency. Kussmaul's five categories of error is utilized in analyzing news feature data. Findings indicate that translation errors occur in news feature translations. Even though literal translation is widely used in translating news feature, certain facts and meanings cannot be conveyed in the target news language which subsequently create problems among target readers in understanding the news feature main messages. These translation errors can be categorized into five categories, i.e. cultural adequacy, situational adequacy, speech act, word meaning and language. Among these, errors in language received the highest frequency (35\%) and the least frequent common error is cultural adequacy (1.6\%). Hence, this study gives insights towards the type of translation errors that occur in news feature translation and have potential implications for news agencies and news translators. Both parties may use these findings in improving news feature translation process and enhance the final news feature product quality.
\end{abstract}

Keywords: Error Analysis, Translation, Quotations, Online News Feature.

\section{Introduction}

Online communication starts in the 1970s and began to grow more rapidly in the 1990s (Gunter, 2003). The term online is used to describe access to digital information, acquisition and dissemination of information (Ward, 2002). In Malaysia, the use of technology in the mass media industry has developed and increased rapidly since the 1980s. New media through the existence of technology brings fresh dimension in conveying messages and boosts up the method of delivering information to the public (Alivi, Ghazali, Tamam, \& Osman, 2018). It provides an alternative way to gather information in place of traditional and conventional media. Therefore, news agencies and newspaper companies began to apply computer technology in the news writing and production processes. In 
INTERNATIONAL JOURNAL OF ACADEMIC RESEARCH IN BUSINESS AND SOCIAL SCIENCES Vol. 10, No. 7, July, 2020, E-ISSN: 2222-6990 @ 2020 HRMARS

addition to print news, Malaysian newspaper companies started to introduce online newspaper services to the public.

Online newspaper websites in Malaysia are comprised of mainstream and alternative (tabloid) newspapers. The first newspaper company in Malaysia offering online news service was the Star Publications which introduced Star Online in 1995 (Bathi, 2002). Besides the Star, other mainstream newspapers in Malaysia that currently provide online services are Berita Harian, Utusan Malaysia and The New Straits Times. The online tabloid newspapers include Kosmo, Harian Metro, The Malay Mail and The Sun, the only free and advertisement-supported newspaper in the country. Online newspapers are not restricted to one language, as Berita Harian, for example, provides news reports in both Malay and English. Although going online, these newspapers still make available to the public their print newspapers. Nevertheless, the Malay Mail has decided to go fully digital when it printed its last print edition on 1 December 2018, and since then can only be accessed online.

Despite differences in the online and printed versions, similar news sections can be found in these newspapers such as hard news, sports, entertainment, economy, features, and others. Features, in particular, sees an increase in the coverage offered by these newspapers, the result of change of reading habits among readers, particularly the younger generation, who are more interested in light and entertaining news compared to the older generation who prefer hard news. According to Friedlander \& Lee (2008), news feature is a creatively written news stories in the form of interesting essays. It aims to inform and entertain the reader. News feature cover various issues within the scope of human interest. Therefore, any event or happening that are able to attract the public's interest are considered and may be turned into news feature articles.

\section{Quotations in News Feature}

The main difference between hard news and news feature is the way the news is reported. News feature focuses on the way the news is presented rather than on its content (Md. Salleh, 1984). Further differences between news and feature stories may be generalized as in Table 1 below:

Table 1 Difference between News and News feature

\begin{tabular}{|l|l|l|}
\hline Criteria & News & News feature \\
\hline Aim & information & information, entertainment \\
\hline Content & short and concise & long and detailed \\
\hline Language & reporting & descriptive and creative \\
\hline Focus & event/happening & $\begin{array}{l}\text { event/happening, human } \\
\text { interest }\end{array}$ \\
\hline Nature of writing & $\begin{array}{l}\text { objective (journalist does not } \\
\text { express personal opinion) }\end{array}$ & $\begin{array}{l}\text { subjective (journalist } \\
\text { expresses personal opinion) }\end{array}$ \\
\hline Timeline & influenced by time & not influenced by time \\
\hline
\end{tabular}

Readers and emotions play important roles in news feature writing as readers' reactions and emotions are prominent characteristics of news feature (Aamidor, 1999). Accordingly, quotations direct and indirect - are used widely in news feature. Quotations serve many purposes to the 
INTERNATIONAL JOURNAL OF ACADEMIC RESEARCH IN BUSINESS AND SOCIAL SCIENCES Vol. 10, No. 7, July, 2020, E-ISSN: 2222-6990 @ 2020 HRMARS

journalist. According to Jullian (2011), quotations can give credibility to the journalist's news report, add flavour to the story, prevent the writer from being held responsible for the content of the quotes, present different perspectives of the event, and others. Nevertheless, some usage may become controversial particularly when there are claims of misquotations or misinterpretations of the speakers' statements. This holds true for both original news feature as well as the translated version. Hence, this study is an attempt to add to the understanding of the problems of misquotations or misinterpretations in news features, particularly in the translation of Malay quotations into English, from the perspective of error analysis.

\section{Literature Review}

Research studies on news quotations in various news media can be found in a number of studies (See among others, Lopez Pan, 2010; Jullian, 2011; Harry, 2013; and Viboonchart \& Gampper, 2014). However, studies on the translation of quotations are less available (See Ya-Mei Chen, 2009). Many researchers have used different linguistic devices to analyze the use of quotations in news stories. López Pan's (2010) study on direct quotations in Spanish print newspapers found that sometimes the printed quotes are different from the actual quotes uttered by the speakers. This change results in misinterpretations on the part of the readers. Using journalistic stylebooks and textbooks as the representative references on quotation writing, López Pan later compares samples of quotation written by journalists and analyze them to ascertain whether the journalists possess the proper knowledge on writing quotations.

Viboonchart \& Gampper (2014) compare news reports of the New York Times (NYT) and the Bangkok Post (BKP) on demonstrations held by the Red Shirt protesters in Thailand in 2010. Using critical discourse analysis on direct quotations and lexical word choice in the two newspapers, they conclude that the NYT supports the protesters while the BKP sided with the Thai Government.

Particular instances of misquotation or misinterpretation may well be the result of mediation by journalists pursuing certain agenda, either professionally or personally. According to Jullian (2010), journalists very often make use of quotations to subtly present a certain image of the news source such that the speaker may appear positive, intelligent, kind, attractive, etc., or on the other hand, unintelligent, cruel or unattractive. Her observation is supported by Harry (2013: 1) who analyses quotations in various Western news newspapers on the Israeli commandos' killing of passengers aboard a pro-Palestinian cargo ship, on May 31, 2010. Utilising the semiotic-linguistic perspective, he suggests that "each quote mode performs as either a source or writer-centered double duty speech act, allowing journalists within the traditional objectivity norm to variously provide relatively neutral or highly interpretive re-voicings of propositional assertions originally uttered by news sources."

Certainly, instances of misquotation or misinterpretation of news sources occur during the processing of original news stories as well as their translations. Particular news process, such as editing, plays a big role in shaping the news in both the original and translated news stories. Chen's (2009) study on China's anti-secession law compares news reports from the New York Times and the Washington Post, and their trans-edited Chinese versions from the China Times, the United Daily News and the Liberty Times in Taiwan. According to Chen, during news trans-editing, news organizations make use of gatekeeping and adaptation features to produce suitable target texts and as such news transediting is always mediated in one way or another. 
Whether news quotations are distorted due to the news translator's mediation or simply because of poor journalistic writing/editing skill, or inappropriate translation procedures, errors do affect the readers, the least of which is the hampering of understanding of the news information. One of the methods of analyzing the effect of news misquotations or misinterpretations is through error analysis. Error analysis has been used in various studies in diverse fields including language learning and translation.

From the language perspective, error analysis is conducted to examine errors that occur in second language teaching and learning (Norfazlika, 2013; Amara, 2015). Language errors are considered as important issue especially in language classes that involved teaching and learning activities (Odlin, 1989). Educators or researcher mainly used error analysis to identify problems in language learning or educational setting. Amara (2015) states that error analysis helps a teacher by giving information about the progress of a language learner. An expert learner will definitely make less mistakes than a novice learner, or expert learner might make mistakes in certain aspects different from other type of learners. Further, error analysis will give evidence on how a language is acquired and learners' strategies in language learning. Thus, learners make mistakes in order to learn and teachers learn from the mistakes to help them. It is also emphasized that making errors should not be regarded as undesirable to the proper processes of language learning. Errors have systematic patterns and may give valuable insights into language acquisition among language learners.

Odlin (1989) asserts that spelling errors, for example, are influenced by spelling conventions of words. He believes pronunciation of a word contributes to spelling error. The closer the pronunciation and writing convention between languages, the easier it is to spell a word. Thus, students will have more difficulties spelling words from languages which are pronounced and written differently from their own. This also relates to the factor of borrowing words into the target language, where the spelling is adapted to the target language pronunciation.

Scholars such as Tan (1990) and Sager (1983) have commented on errors in terms of word meaning. Tan (1990) argues that there are two factors that cause error to occur. First, the translator does not understand the original intended meaning of the speaker. Thus, the translation is inaccurate. Second, the translator understood the meaning of the speaker but is unable to translate the meaning into the target text. This second problem arises due to the translator's lack of proficiency in the usage of language and interpreting the speaker's meaning. In addition, a translator needs to ensure that the intended meaning of the speaker's speech remains. Sager (1983) discusses the linguistic, semantic and pragmatic effects of errors in translation caused by the deletion, addition, deviation and modification procedures as well as error in understanding the meaning of the source text.

Kussmaul (1992) states that the more fundamental the error, the greater the impact of the error towards readers' understanding of a text. He suggests five categories of errors that can be used to analyze and evaluate a translated text, i.e., cultural adequacy, situational adequacy, speech act, word meaning and language error. Since translation studies differs from language learning, translators should take into account the impact of language error on each assessment made. Thus, translators need to consider whether errors such as sentence structure, or misspelling which carry a higher weightage in language learning, may cause loss of meaning in the translation text. 


\section{Problem Statement}

According to Bielsa \& Bassnett (2009), news agencies practice translation effectively. Technology and skills to produce accurate and fast translation are applied as an effort to disseminate variety of news to everyone in the world. Therefore, translation process is taking place in the news media in order for readers to access online newspaper in multiple language versions. Previous research studies on news translation focus on newspaper readership (Margaret \& Hellen, 2014), news translation strategies (Rokiah, 2000), cultural aspects in news translation (Conway, 2010), and newspaper language (Odlin, 1989; Bell, 1992; Kussmaul, 1995). As not many research have been attempted on error analysis in news feature, this research paper intends to add to the knowledge by researching on error analysis from the perspective of translation studies.

\section{Research Objective}

The two objectives of this research paper are as follows:

i. To identify and classify types of error in online news feature translation.

ii. To analyze the error pattern and suggest general guidelines on how to minimize errors in news feature translation.

\section{Methodology}

1. News feature published in the Malaysian national news agency, BERNAMA, are collected as data. Quotations are identified and extracted from selected feature stories. A quotation is the transcription of what someone has said, which is recorded or written by reporters during interviews, speeches etc. There are two types of quotations, i.e., direct and indirect quotations (Stovall, 2005). The data are analyzed based on five categories of errors by Kussmaul (1995). The summary for the five categories of errors is as follows:

i. Cultural adequacy. The translator should take into account cultural factors that are involved when translating quotations. Speakers in the news feature are from various backgrounds, thus words spoken by the speakers must also contain cultural elements.

ii. Situational adequacy. The translators need to ensure that the translated passage or quotations are appropriate to the situation. This is due to the fact that situation plays an important role in the selection of quotations and the way in which quotations are translated into news articles.

iii. Speech act. The translator needs to consider language acquisition because quotation is a type of speech, so it is important to specify the types of sentences that the speaker uttered.

iv. Word meaning. The translator must ensure that the intended meaning a speaker is trying to convey is well understood by the target reader. If a translation fails, the reader may assume that the speaker is the person who has provided the incorrect information.

v. Language error. An interview especially news feature reporting is conducted in a relaxed and non-formal conversation. Therefore, speakers tend to adopt a nongrammatical style and inevitably commits language mistakes in speech. In addition, journalists also make language mistakes while writing and translating quotes. Translators should take into account this human factor error before translating to avoid preserving the error in the target language news. 
INTERNATIONAL JOURNAL OF ACADEMIC RESEARCH IN BUSINESS AND SOCIAL SCIENCES Vol. 10, No. 7, July, 2020, E-ISSN: 2222-6990 @ 2020 HRMARS

3. Error patterns from these five categories are analyzed and discussed.

4. General guidelines on how to minimize the error in news feature translation will be suggested as a contribution and implication of this research.

\section{Conceptual Framework}

Based on the methodology, a conceptual framework is developed and presented as below:

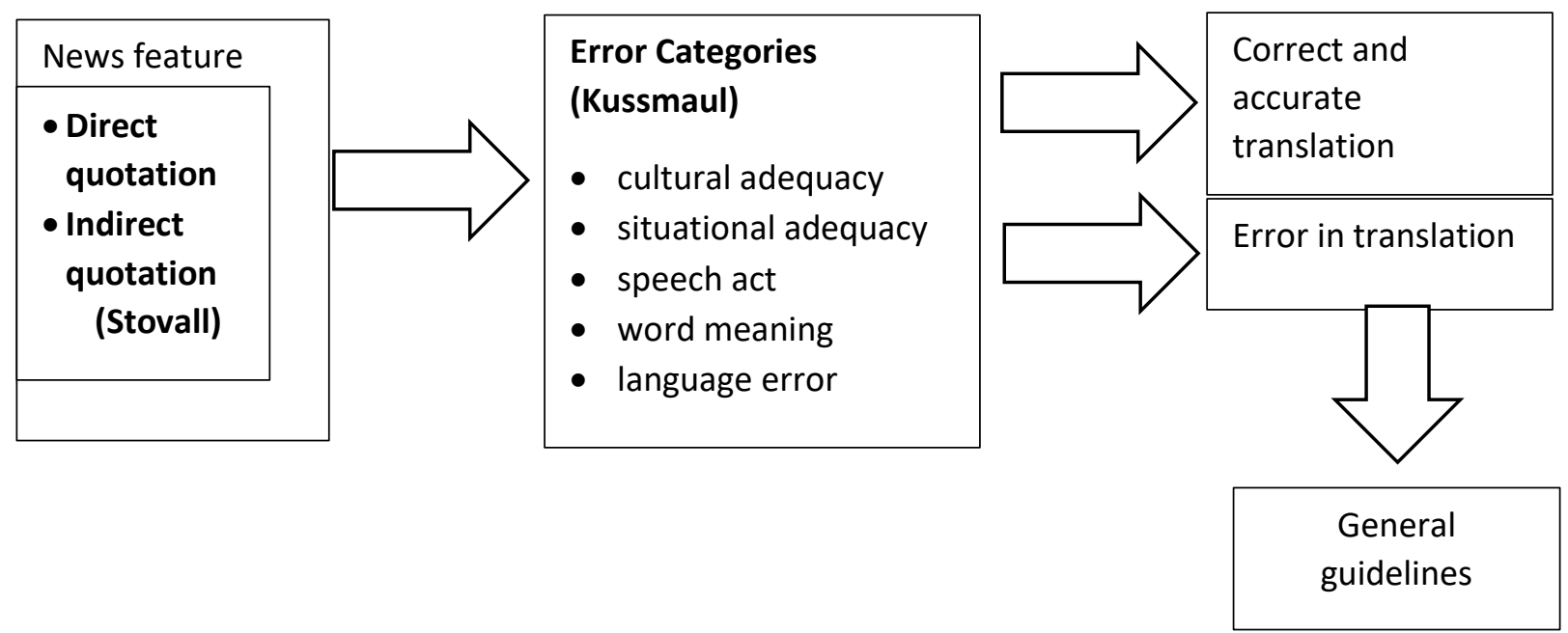

Figure 1: Conceptual Framework

\section{Data Analysis}

\section{i. Cultural adequacy}

The first category of Kussmaul's error analysis is cultural adequacy. According to Newmark (1988:94), culture is "the way of life and its manifestation that are peculiar to a community that uses a particular language as its means of expression." Generally, words that contain cultural elements are easily recognizable because they are closely related to a particular language. Any effort to literally translate cultural word will most probably involve a loss of meaning. In other words, the translator or journalist needs to identify any cultural elements that are available in the source text and makes a decision either to borrow the source language cultural word in the target language or modify it according to the target language cultural context.

\section{Example 1}

Malay Version (Source Text, ST)

Pairin berkata antara pengisian dalam perayaan Pesta Kaamatan ialah mengadakan upacara 'Magavau' untuk memuja semangat padi dan turut diadakan pemilihan Unduk Ngadau Kaamatan (Ratu Cantik Kaamatan) sebagai memperingati pengorbanan dan nilai-nilai murni yang diteladani melalui legenda Huminodun.

\section{English Version (Target Text, TT)}

Pairin said among the activities held during the Kaamatan festival is the 'Magavau' ceremony to pray for the rice spirits and also the selection of the pageant queen or the 
Unduk Ngadau Kaamatan to commemorate the sacrifice and positive values gathered from the Huminodun legend.

This news feature article is based on the celebration of the Kaamatan Festival in Sabah. The speaker, Datuk Seri Joseph Pairin Kitingan's explanation on the Magavau ceremony is written in an indirect quotation. This type of quotation is identified based on the absence of quotation marks (Stovall, 2005). Other than the speaker's explanation, the journalist and translator also include information that the Magavau ceremony is a special celebration in honor of Bambarayon, a specific spirit that is honored and worship in this society. The festival is a tradition of the Kadazandusun people and is usually held after the paddy harvest. In this example, the translator preserves the source text style of writing and translates almost every single words. However, the difference between Malay and the English language is considered in order to produce an accurate text in terms of word spelling, grammar and syntax.

The cultural phrase in the ST is 'semangat padi' and it is translated into 'rice spirits' in English. However, the English version may confuse the target reader. This ambiguity or misunderstanding may occur because the word 'padi' is specific and refer to a type of plant. The 'rice' equivalent given by the translator denotes three types of interpretation, that is, a type of cooked food (nasi), raw food (beras) or plant (pokok padi). Readers who read the original text in Malay language may easily identify the intended meaning as a spirit that inhabits a paddy plant. It is a cultural phrase and can only be understood by people who live in the specific place or geography. Even though rice is an accurate translation for padi, the entire phrase may raise a different interpretation, i.e., a spirit that lives inside food (a product of harvested plant). Therefore, this error analysis gives us insights in translating cultural elements.

First, the translator needs to consider the cultural elements embedded in a word. Every community and language user has their own interpretation of cultural words. This is due to the fact that many words have denotative and connotative meanings according to their specific usage. Second, the translator should decide whether he or she wants to retain the original meaning by borrowing that cultural word into the target language or choose to give the closest equivalence in the target language. Third, whatever the option taken by the translator, he or she must maintain the function and meaning of an indirect quotation as it still represents the message which has been uttered by the speaker himself/herself.

\section{ii. Situational adequacy}

According to Kussmaul (1995), the second category of error analysis is situational adequacy. This type of translation error is judged by the situation or context of the source text and the target text. Situational or commonly used words, whose context may refer to a specific condition can be understood from reading the whole sentence or paragraph. Target readers usually develop an understanding of the speaker's background or the news feature context through words that have additional meaning within it.

Example 2

Malay Version (Source Text, ST) 
INTERNATIONAL JOURNAL OF ACADEMIC RESEARCH IN BUSINESS AND SOCIAL SCIENCES

Vol. 10, No. 7, July, 2020, E-ISSN: 2222-6990 @ 2020 HRMARS

"Gembira kerana di sini dapat pitih (wang) lebih. Anak-anak pun dah pergi negara lain belajar," katanya.

English Version (Target Text, TT)

I am happy staying here, can get the money and my children can go abroad for further education," she said with a smile.

This second example is a direct quotation in another news feature. In direct quotation, the speaker's word is written word for word and inserted within quotation marks (Stovall, 2005). This story is written based on a settlement known as Kampung Bujang, in the southern province of Narathiwat, Thailand, where the speaker, Tania Kelian, speaks in an informal style. In the Malay version, the speaker mentions the word pitih, the word used by the people in Kampung Bujang to refer to money. The journalist retains the speaker's original utterance and at the same time tries to avoid misunderstanding among the ST readers by adding 'wang', literally money' beside the word 'pitih'. This addition procedure is marked by parentheses usage. Therefore, the situational information is preserved in the ST when the journalist retains the original word used by the speaker. The word pitih differentiates the speaker's geographical location as it is specific to the speaker's hometown and subsequently, provides situational information to the readers.

However, the translator fails to retain the geographical dimension when he translates the word pitih with money. This word choice brings the same meaning but neglect the situational information. The word money in English language is generic and may refer to various types of currency, eg. Dollar, Pound Sterling, Thai bhat or ringgit Malaysia. In the direct quotation, the reader does not obtain the geographic origin and information, that is, the speaker speaks with a Malay Pattani accent as pitih, is not retained in the translation. In this situation, it is advisable for the translator to borrow the word pitih in English and add an explanation (the local word for money) or simply add the word (money) beside pitih to further clarify its meaning.

\section{iii. Speech act}

The third category of error analysis according to Kussmaul (1995) is speech act. Speech act refers to an utterance that contains underlying pragmatic meaning. In this research paper, the main focus is the utterance of meaning in direct and indirect quotations. Findings indicate that differences in speech meaning may occur as a result of verb usage or attribution verb used in both types of quotation. Attribution in news reporting generally refers to who is being quoted as the source of the journalist's story.

\section{Example 3}

Malay Version (Source Text, ST)

"Bila sudah ada generasi warisan perniagaan ini, kita hanya perlu membantu mengembangkan perniagaan dan bukan lagi memulakan perniagaan," tegas Othman dalam wawancara dengan Bernama di pejabatnya di Bangunan Mara di sini baru-baru ini.

English Version (Target Text, TT) 
INTERNATIONAL JOURNAL OF ACADEMIC RESEARCH IN BUSINESS AND SOCIAL SCIENCES Vol. 10, No. 7, July, 2020, E-ISSN: 2222-6990 @ 2020 HRMARS

"When the generation is ready to take over, we only need to assist in expanding the business instead of starting all over again", Othman told Bernama in his office at Mara building here recently.

This third data is also a direct quotation used in a news feature. The example indicates that the translator made changes while translating the attribution verb. The translator translates tegas (stressed) as 'told' in the English version. This equivalent is not the same as 'stressed'as tegas implies that the speaker stressed or emphasized his opinion on the role of Mara in expanding the business and not to help start the business. Instead, the word 'told' (past tense of tell) is simply to inform the TT reader that the speaker is giving a statement to the reporter. Thus, the element of emphasis in the speech of the speaker is not preserved in the direct quotation. In order to retain the original meaning, a translator needs to make sure that the attribution verb is translated correctly in the target language and at the same time produces the same connotation. This is because, a mistranslation in attribution verb can cause the tone of the spoken language to be lost or changed in the news feature reports. For example, rather than emphasizing an opinion, it is changed to simply telling the journalist about something. Other attribution equivalents that are used in this research data are as follows.

Table 2 Types of Attribution Used in Quotations

\begin{tabular}{|l|l|c|}
\hline Source Text & Target Text & Total \\
\hline \multirow{3}{*}{ kata (say) } & said & 162 \\
\cline { 2 - 3 } & noted & 12 \\
\cline { 2 - 3 } & told & 8 \\
\cline { 2 - 3 } & added & 6 \\
\hline menurut (according to) & according to & 14 \\
\hline cerita (story/ tell) & said & 14 \\
\hline menjelaskan (explain) & said & 8 \\
\hline tambah (add) & said & 5 \\
\hline
\end{tabular}

Table 2 indicates the translator's tendency to replace various Malay attribution verbs with just one English equivalent, i.e., 'say' (present tense) or 'said' (past tense). This action may generalize the speaker's manner of speaking and gives a neutral connotation to the target readers.

\section{iv. Word Meaning}

Kussmaul's (1995) fourth category of error analysis is word meaning. Errors in the word meaning are usually evaluated based on the weightage of translation equivalence errors. The difference in the level of meaning error may occur because errors can be categorized into (i) overtranslation, i.e., the translator adds redundant or unneeded information in the TT, (ii) undertranslation, i.e., the translator omits certain information that is crucial to retain the speaker's fundamental or original meaning, and (iii) mistranslation, i.e., a translation that alters the overall message and function of the text. The third error is considered the most fundamental error and the translator needs to avoid mistranslating any direct or indirect quotation as it may affect the speaker's reputation or the newspaper agency's integrity. 
INTERNATIONAL JOURNAL OF ACADEMIC RESEARCH IN BUSINESS AND SOCIAL SCIENCES

Vol. 10, No. 7, July, 2020, E-ISSN: 2222-6990 @ 2020 HRMARS

\section{Example 4}

Malay Version (Source Text, ST)

"Ibu bapa juga berpeluang melawat anak-anak mereka lebih kerap, kerana untuk sampai ke Medan hanya mengambil masa lebih kurang sejam setengah (penerbangan)," katanya.

English Version (Target Text, TT)

"Parents too will be able to visit their children more often, as it is only one hour by flight to Medan," he said.

This fourth data is a direct quotation that gives two different interpretations. This is due to the inconsistency in the flight time between the ST and the TT. The information in the TS shows the time of 'sejam setengah' (an hour and a half) while the TT shows the time of one hour. This mistranslation is considered a serious error because the overall meanings of both utterances are different. If a reader reads and uses this information as a guide when planning a trip, problems may arise due to error in calculating the time required for the trip, plus the reader may also miss his flight. The tendency of a reader to compare both information for any discrepancy is very low, since hardly anyone buys newspapers in two languages to compare and contrast both information. In addition, this data is written in the form of direct quotation. The translator must ensure that the translation equivalence is consistent with the speaker's speech. Therefore, the best action to be taken in this case is to give the correct translation of the time concerned, i.e., one and a half hour or 90 minutes.

\section{Example 5}

Malay Version (Source Text, ST)

"Kerajaan menanggung kos perang antara RM130 juta hingga RM150 juta setahun. Saya masih ingat semasa bersekolah di Penang Free School, kami diberitahu guru sejarah bahawa kerajaan menanggung kos RM1 juta sehari untuk memerangi komunis. Itu baru kos yang ditanggung kerajaan negara ini tidak termasuk pasukan tentera Inggeris dan Komanwel," kata Omar.

\section{English Version (Target Text, TT)}

"The Emergency had cost the government between RM130 million and RM150 million a year. I remembered during my days in the Penang Free School, the teacher told us that the war against the communists cost the Malayan government RM1.0 million a day," said Omar.

This second example under the word meaning category shows that translators also make mistake by translating a specific word with a generic equivalent in the target language. For example, the term 'history teacher' is specific in the ST and it refers to a teacher who specializes in history and teaches that particular subject at school. However, a 'teacher' may refer to anyone who teaches any subjects. This data shows that the usage of an omission procedure will affect the meaning of a word and overall meaning of an utterance. The word 'history' has been omitted and is not translated in the TT. Ideally, the best translation decision is for the translator to provide the teacher's background, i.e., a 'history teacher' in order to inform the readers. However, misunderstanding of the speaker's intended 
INTERNATIONAL JOURNAL OF ACADEMIC RESEARCH IN BUSINESS AND SOCIAL SCIENCES Vol. 10, No. 7, July, 2020, E-ISSN: 2222-6990 @ 2020 HRMARS

meaning is not very severe as readers can usually understand that the speaker is referring to a teacher. In addition, the context of the direct quotation, i.e., the struggle against the Communist, can provide information on the subject that the teacher is teaching, which is history. Thus, the meaning of the speaker can still be understood by the readers even though there is a difference in meaning between the word 'teacher' and the term 'history teacher'.

\section{v. Language}

The fifth category of error analysis according to Kussmaul (1995) is language error. Language error in this news feature data can be further classified into two stages. In the first stage, the speakers make mistakes and the journalists retain the mistakes. This is because the speakers are using informal language or incorrect grammatical sentences during the interviews. Typically, the use of non-formal or grammatical sentences can be seen in the writing of direct quotations. This type of language mistake is hard to avoid, since human make mistakes especially when they say something spontaneously. The second stage is when journalists and translators make language mistakes such as incorrect spelling, missing space between word, missing of punctuation marks and others, as can be seen in the following examples:

Example 6

Table 3 Examples of Language Error

\begin{tabular}{|l|l|}
\hline Error & Correct \\
\hline daripafa & daripada \\
\hline pelrbagai & pelbagai \\
\hline countand & country and \\
\hline kereta apa & kereta api \\
\hline kajayaan & kejayaan \\
\hline iniu & ini \\
\hline Lady williams & Lady Williams \\
\hline "me and my family... " & "Me and my family... " \\
\hline news paper & newspaper \\
\hline Tan berkata... lemak dan garam & Tan berkata... lemak dan \\
& garam. \\
\hline "Our target is... holidays. & "Our target is ... holidays. " \\
\hline
\end{tabular}

\section{Discussion}

Based on the data analysis, the translators made five types of mistake in translating direct and indirect quotations. The five errors are (a) cultural adequacy (b) situational adequacy (c) speech act (d) word meaning, and (e) language error. The frequency of language errors is 21 times, speech act errors (16 times), situational adequacy (13 times) and word meaning errors ( 9 times). Last but not least, only one cultural adequacy error (1.6\%) is present in this data. Hence, the analysis shows that errors or mistakes exist in the news feature translation. Information on the types of error, frequency and percentage of errors can clearly be seen in Table 4 below: 
INTERNATIONAL JOURNAL OF ACADEMIC RESEARCH IN BUSINESS AND SOCIAL SCIENCES Vol. 10, No. 7, July, 2020, E-ISSN: 2222-6990 @ 2020 HRMARS

Table 4 Types of Error

\begin{tabular}{|l|l|l|}
\hline Type of Error & Frequency & Percentage \\
\hline cultural adequacy & 1 & $1.6 \%$ \\
situational adequacy & 13 & $21.7 \%$ \\
speech act & 16 & $26.7 \%$ \\
word meaning & 9 & $15.0 \%$ \\
language & 21 & $35.0 \%$ \\
\hline Total & 60 & $100 \%$ \\
\hline
\end{tabular}

The findings show that language error frequency is higher compared to other categories in news feature translation. This type of error may occur due to the translator's carelessness and his/her decision to be faithful to the speaker's sentence structure. Hence, the sentences in the source text and the translation text seem less grammatical, appear awkward and too literal. The effects of language errors are often considered to be non-serious because readers usually understand the word meaning based on the sentence context. However, language errors can affect the fluency of the news passage and the reader's reading pace.

Errors such as ungrammatical sentences, misspellings, punctuation errors and others can be avoided if journalists and translators allocate enough time to check the spellings and grammar in the news feature article. Additionally, editors and proofreaders also need to play an important role in reviewing news feature writing so that they are able to minimize the language errors. Good and competent knowledge in grammar skill should also be emphasized to convey an accurate news feature reporting.

Speech act mistakes are caused by errors in the use of attribution verbs. This error recorded the second highest number because attribution verbs are used in every direct and indirect quotations. The news agency style or the translator's preference for the word 'say' or 'said' also lead to misinterpretation of the speech act in the target language. Thus, the exact information about the type of speech delivered by the speaker is not successfully communicated to the readers whenever an attribution verb is replaced inappropriately. Therefore, translators should be more careful when conveying the verb to ensure that the translated information is not changed.

Situational information can be seen when the speakers speak in non-formal or non-grammatical ways which convey the speakers' backgrounds, positions held by the speakers, their educational status, geographical information, time, social class and others. A translator who translates this situational context into standard English obviously does not consider the situational factors inherent in the source text. This action results in the situation where the information is unable to be retained in the target text. Translators and journalists also need to consider situational contexts in order to use dialects, and formal or informal languages which are considered appropriate for writing direct and indirect quotes in news feature articles.

Errors in the meaning of words are also found in the translation of direct and indirect quotations. Misinterpretations of words can occur when a translator does not fully understand the message a speaker is trying to convey. Consequently, there is a situation where the meaning of the quotations in the source text and the target text are inconsistent. Data analysis shows that a translator's incorrect interpretations of meaning contributes to errors in providing accurate word match, and also 
INTERNATIONAL JOURNAL OF ACADEMIC RESEARCH IN BUSINESS AND SOCIAL SCIENCES Vol. 10, No. 7, July, 2020, E-ISSN: 2222-6990 @ 2020 HRMARS

application of paraphrasing procedures results in changes of meaning. Meaning error can cause the passage function to change. Therefore, it is recommended that the translator identifies the message that the speaker is trying to convey and not to be overly faithful towards the source text structure.

Direct and indirect quotations in news feature articles also contain cultural information although only one example can be found in this study. This is due to the fact that the source text does not contain many cultural words nor complex cultural words which are difficult to translate. Cultural errors occur when translators do not provide appropriate translations that refer to a particular culture or a community way of life. This error also occurs because the translator does not understand the implicit or connotative meaning of a word. Therefore, translators should always check whether a word has a specific meaning used in a particular community. Additionally, translators should also have reference books to identify and understand cultural word concepts. Thus, translators should be able to identify words that have cultural meanings and provide translations that maintain cultural meaning within the target text.

\section{Conclusion}

The findings of this study reveal that there are many factors that contribute towards error in news feature translation, i.e, the journalists and translators lack of competency in writing and translating news feature, differences in grammar and spelling systems between Malay and English language, direct and indirect quotation style, and news agency preference in writing news feature. The errors can be classified into five categories, namely, cultural adequacy, situational adequacy, speech act, word meaning and language. These errors are discussed and some recommendations are made in the previous section. Therefore, it is hoped that these findings can help translators and journalists identify the types of error in news feature reports and the means of correcting them in order to produce good quality translations.

Overall, the research has yielded theoretical and contextual contributions to the field of translation and the profession of journalism. Theoretically, the study proves that error analysis research provides added value to translation studies. The findings support other research findings that translation quality may be observed through error analyses of good as well as weak translations and thus rejecting the general assumption that the process of learning can only be conducted through the use of good translation samples. Subsequent suggestions, drawn from the findings, may be made to improve weak translations. The findings also help researchers to explore additional methods of studying translation quality other than the common method of observing translation quality through particular parameters. Contextually, the research data which comprises of actual news features, selected from a prominent news agency in Malaysia, provides news organizations with exemplary contextual guideline to translating news quotations.

\section{References}

Aamidor, A. (1999). Real feature writing. Mahwah, New Jersey: Lawrence Erlbaum Associates Publishers.

Alivi, M. A., Ghazali, A. H. A., Tamam, E., \& Osman, M. N. (2018). A review of new media in Malaysia: Issues affecting society. International Journal of Academic Research in Business and Social Sciences, 8(2), 12-29. 
INTERNATIONAL JOURNAL OF ACADEMIC RESEARCH IN BUSINESS AND SOCIAL SCIENCES

Vol. 10, No. 7, July, 2020, E-ISSN: 2222-6990 @ 2020 HRMARS

Amara, N. (2015). Errors correction in foreign language teaching. The Online Journal of New Horizons in Education. 5 (3), 58-68.

Bielsa, E., \& Bassnet, S. (2009). Translation in global news. London: Routledge.

Brown, C. H. (1957). Informing the people. A basic text in reporting and writing the news. New York: Hastings House Publishers.

Chen, Y-M. (2009). Quotation as a Key to the Investigation of Ideological Manipulation in News TransEditing in the Taiwanese Press La citation comme élément-clé d'investigation du biais idéologique dans la transédition des informations de la presse taiwanaise, TTR Traduction, terminologie, redaction, TTR, 22 (2), 203-238

Conway, K. (2010). News translation and cultural resistance. Journal of International and Intercultural Communication, 3(3), 187-205.

Friedlander, E. J., \& Lee, J. (2008). Feature writing for newspapers and magazines. The pursuit of excellence. Sixth Edition. Boston: Pearson/ Allyn \& Bacon.

Gunter, B. (2003). News and the net. Mahwah, New Jersey: Lawrence Erlbaum Associates Publishers.

Harry, J. C. (2013). Journalistic quotation: reported speech in newspapers from a semiotic-linguistic perspective, Journalism, 0(0) 1-18.

Jullian, P. M. (2011). Appraising through someone else's words: The evaluative power of quotations in news reports, Discourse \& Society, 22(6), 766-780.

Kussmaul, P. (1995). Training the translator. Amsterdam \& Philadelphia: John Benjamins Publishing Company.

Pan, L. F. (2010). Direct quotations in Spanish newspapers. Literality according to stylebooks, journalistic textbooks and linguistics research, Journalism Practice, 4 (2), 192-207.

Kassim, M. (1984). Kewartawanan teori dan praktis. Kuala Lumpur: Dewan Bahasa dan Pustaka.

Newmark, P. (1988). A textbook of translation. New York: Prentice Hall.

Ngugi, M. N., \& Mberia, H. K. (2014). The influence of the Internet surfing on the reading culture of secondary school teachers: A case study of newspaper readership in Kigumo sub county, Kenya. International Journal of Academic Research in Business and Social Sciences, 4 (11), 96-110.

Abd. Karim, N. (2013). An analysis of speech errors of English as a second language learners in UiTM Negeri Sembilan. Social and Management Research Journal, 10(2), 1-23.

Odlin, T. (1989). Language transfer. Cross-linguistic influence in language learning. Cambridge: Cambridge University Press.

Awang, R. (2000). The Translation of English News into Malay in The Malay Newspapers of Malaysia. PhD Thesis. Penang: Universiti Sains Malaysia.

Sager, J. C. (1983). Quality and Standards - the Evaluation of Translation. In the Translator's Handbook. (Picken, C., ed.), 121-128. London: Aslib.

Stovall, J. G. (2005). Journalism: Who, what, when, where, why and how. Boston: Pearson/ Allyn \& Bacon.

Tan, C. L. (1990). Language and translation. Singapore: Hillview Publications.

Viboonchart, N., \& Gampper, C. (2014). The underlying ideologies in news articles: The study through the use of direct quotations and lexical choices in an English newspaper in Thailand and an American newspaper, Asian Social Science, 10(15), 187-198.

Ward, M. (2002). Journalism online. Boston: Focal Press. 